
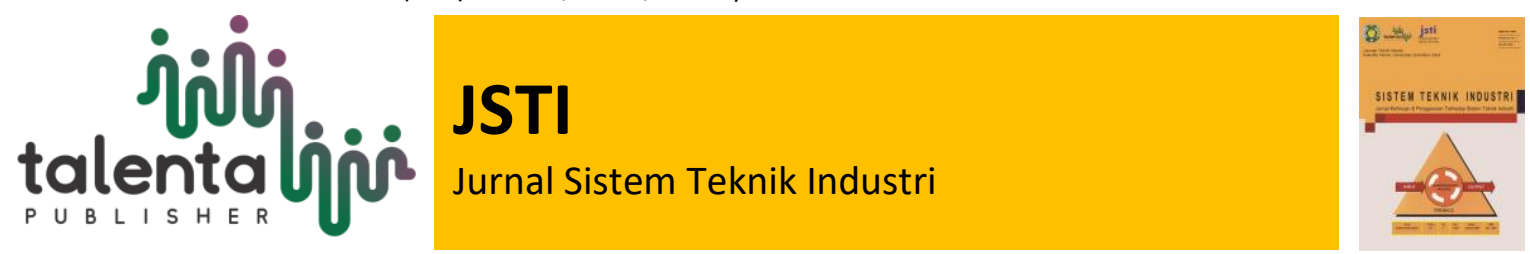

\title{
Analysis of Product Quality Improvements to Reduce Coffee Bean Defects with Six Sigma Method
}

\author{
Sri Wahyuni Matajang ${ }^{1}$, Erlinda Muslim ${ }^{2}$ \\ ${ }^{1,2}$ Department of Industrial Engineering, Faculty of Engineering, Universitas Indonesia, Kampus Baru \\ UI Depok, 16424, Indonesia
}

\begin{abstract}
Rapid technological developments have led to increasingly fierce competition, especially in the coffee industry. PT XYZ as a company engaged in the processing of coffee beans must continue to improve the quality of products in order to continue to compete. However, in the last 3 years there has been an increase in the number of defective coffee beans, in 2020 by $21.4 \%$. This thesis discusses how to reduce the level of coffee bean defects by using the quality improvement method by following the stages in six sigma, and looking for the causes of these defects. The calculation results obtained that the DPMO at PT XYZ is 0.1790 and the sigma value is 2.42 . Factors causing the increasing number of defective coffee beans are materials, machines, and the environment. Some of the solutions are to check the time of purchasing raw materials from farmers before buying raw materials from collectors, make and schedule routine inspections of machines or replace machines that are not suitable for use, provide training to operators and make SOPs and work instructions for each job. stations, Purchase of water content detectors for coffee raw materials, and add a green house.
\end{abstract}

Keyword: Coffee Beans, Six Sigma, Quality Improvement

Abstrak. Perkembangan teknologi yang pesat telah menyebabkan persaingan yang semakin ketat, terutama di industri kopi. PT XYZ sebagai perusahaan yang bergerak di bidang pengolahan biji kopi harus terus meningkatkan kualitas produk agar dapat terus bersaing. Namun, dalam 3 tahun terakhir telah terjadi peningkatan jumlah biji kopi yang rusak, pada tahun 2020 sebesar 21,4\%. Tesis ini membahas bagaimana mengurangi tingkat kecacatan biji kopi dengan menggunakan metode peningkatan kualitas dengan mengikuti tahapan dalam six sigma, dan mencari penyebab cacat ini. Hasil perhitungan diperoleh bahwa DPMO di PT XYZ adalah 0,1790 dan nilai sigma adalah 2,42. Faktor-faktor yang menyebabkan meningkatnya jumlah biji kopi yang rusak adalah bahan, mesin, dan lingkungan. Beberapa solusinya adalah dengan mengecek waktu pembelian bahan baku dari petani sebelum membeli bahan baku dari pengepul, membuat dan menjadwalkan pemeriksaan rutin mesin atau mengganti mesin yang tidak layak digunakan, memberikan pelatihan kepada operator dan membuat SOP serta instruksi kerja untuk setiap stasiun kerja, pembelian detektor kandungan air untuk bahan baku kopi, dan menambahkan green house.

Kata Kunci: Biji kopi, Six Sigma, Pengendalian Kualitas

Received 03 November 2021 | Revised 07 January 2022 | Accepted 15 January 2022

*Corresponding author at: Universitas Indonesia, 16424, Depok, Indonesia

E-mail address: sri.wahyuni74@ui.ac.id

https://doi.org/10.32734/jsti.v24i1.7517 Attribution-NonCommercial-ShareAlike 4.0 International.License Some rights reserved Copyright C 2022 Published by Talenta Publisher, ISSN: 1411-5247 e-ISSN: 2527-9408

Journal Homepage: http://talenta.usu.ac.id/jsti 


\section{Introduction}

Currently, technological developments are becoming increasingly rapid, and these technological developments have led to increased competition, especially in the coffee industry. According to International Coffee Organization (ICO) data, there was an increase in the number of exports, production, and consumption of coffee in the world and Indonesia in 2020 [1]. Coffee has become one of the drinks that is quite popular among the public. Loved by young and old alike.

Table 1 World Coffee Consumption and Indonesian Coffee Exports

\begin{tabular}{|l|c|c|c|c|c|}
\hline $\begin{array}{c}\text { (In Thousand Bags (1 Bags } \\
\text { 60kg) }\end{array}$ & $\mathbf{2 0 1 7 / 1 8}$ & $\mathbf{2 0 1 8 / 1 9}$ & $\mathbf{2 0 1 9 / 2 0}$ & $\mathbf{2 0 2 0 / 2 1}$ & $\begin{array}{c}\text { Changes } \\
(\mathbf{2 0 1 7 / 1 8 - 2 0 2 0 / 2 1})\end{array}$ \\
\hline World & $\mathbf{1 6 1 . 3 7 7}$ & $\mathbf{1 6 8 . 4 9 1}$ & $\mathbf{1 6 4 . 5 3 0}$ & $\mathbf{1 6 6 . 6 2 8}$ & $\mathbf{1 . 1 \%}$ \\
\hline Africa & 11.087 & 12.017 & 12.020 & 12.240 & $3.4 \%$ \\
\hline Asia \& Oceania & 34.903 & 36.472 & 36.002 & 36.503 & $1.5 \%$ \\
\hline Central America \& Mexico & 5.273 & 5.431 & 5.352 & 5.364 & $0.6 \%$ \\
\hline Europe & 53.251 & 55.637 & 53.680 & 54.349 & $0.7 \%$ \\
\hline North America & 29.941 & 31.779 & 30.580 & 30.993 & $1.2 \%$ \\
\hline South America & 26.922 & 27.156 & 26.898 & 27.180 & $0.3 \%$ \\
\hline Exporting countries (Crop years) & $\mathbf{4 . 6 8 6}$ & $\mathbf{5 0 . 2 4 4}$ & $\mathbf{5 0 . 0 0 2}$ & $\mathbf{5 0 . 6 6 4}$ & $\mathbf{0 . 7 \%}$ \\
\hline Brazil & 21.997 & 22.200 & 22.000 & 22.400 & $0.6 \%$ \\
\hline Indonesia & $\mathbf{4 . 7 5 0}$ & $\mathbf{4 . 8 0 0}$ & $\mathbf{4 . 8 0 6}$ & $\mathbf{5 . 0 0 0}$ & $\mathbf{1 . 7 \%}$ \\
\hline
\end{tabular}

Table 2 Coffee Production per Year

\begin{tabular}{|l|c|c|c|c|c|}
\hline \multicolumn{1}{|c|}{$\begin{array}{c}\text { In Thousand Bags (1 Bags } \\
\text { 60kg) }\end{array}$} & $\mathbf{2 0 1 7}$ & $\mathbf{2 0 1 8}$ & $\mathbf{2 0 1 9}$ & $\mathbf{2 0 2 0}$ & $\begin{array}{c}\text { \% Changes } \\
\mathbf{2 0 1 9 - 2 0}\end{array}$ \\
\hline Total & $\mathbf{1 6 7 . 8 6 8}$ & $\mathbf{1 7 0 . 2 4 2}$ & $\mathbf{1 6 8 . 6 7 8}$ & $\mathbf{1 7 1 . 8 9 7}$ & $\mathbf{1 . 9 \%}$ \\
\hline Arabicas & 98.187 & 99.873 & 96.816 & 101.875 & $5.2 \%$ \\
\hline Robustas & 69.680 & 70.368 & 71.862 & 70.021 & $-2.6 \%$ \\
\hline India & 5.813 & 5.325 & 4.968 & 5.700 & $14.7 \%$ \\
\hline Indonesia & $\mathbf{1 0 . 5 4 4}$ & $\mathbf{1 0 . 0 7 1}$ & $\mathbf{1 1 . 6 7 5}$ & $\mathbf{1 2 . 2 7 3}$ & $\mathbf{5 . 1 \%}$ \\
\hline Vietnam & 33.432 & 30.283 & 30.487 & 29.000 & $-4.9 \%$ \\
\hline
\end{tabular}

PT XYZ as one of the companies engaged in the coffee industry must continue to improve the quality of the products produced in order to continue to compete. PT XYZ is a coffee factory whose activities include purchasing and processing coffee beans (Arabica coffee consisting of Toraja, Enrekang, and Mamasa Arabica coffees). The activity process of PT XYZ is parchment coffee beans into dried coffee beans ready for export. Parchment coffie is the part of the coffe beab that has been removed from the outsite of the rice crust (cherry) but has not had the protective paddly peel removed. They also call them silk eggplant. The final product produced by this company will then be sold to meet the needs of Arabica coffee beans at the American Starbucks company. However, in the last 3 years there has been an increase in the number of defective coffee beans and in 2020 by $21.4 \%$. 


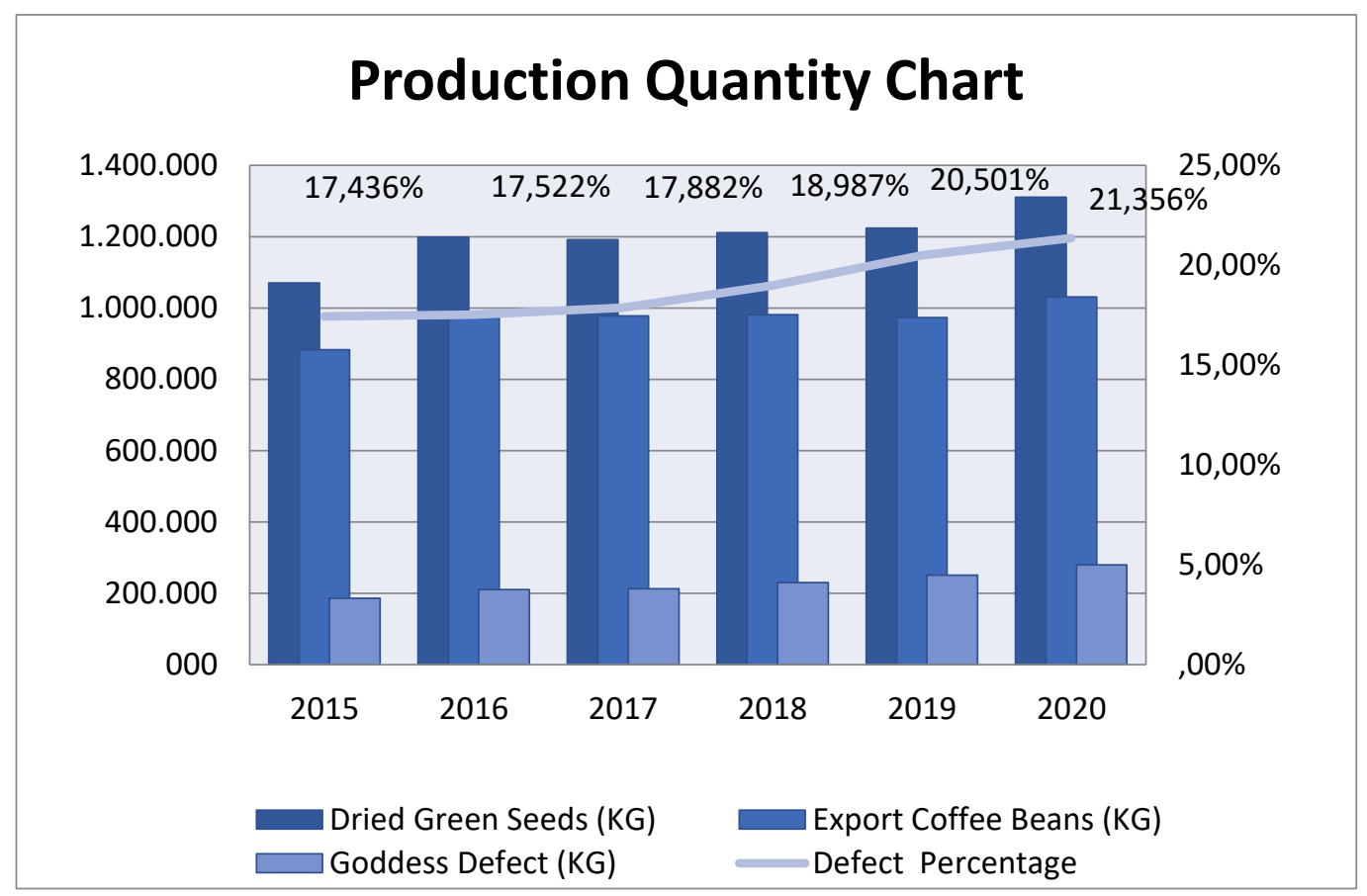

Figure 1 Graph of Production Amount of PT XYZ

In a previous research, Measurement and Analysis of the Productivity with Objective Matrix (OMAX) Method by Sri Wahyuni Matajang in 2020, showed that in the period May 2019 August 2020 PT XYZ experienced fluctuations in productivity, this was due to the large number of defective coffee beans [2].

\section{Performance Index}

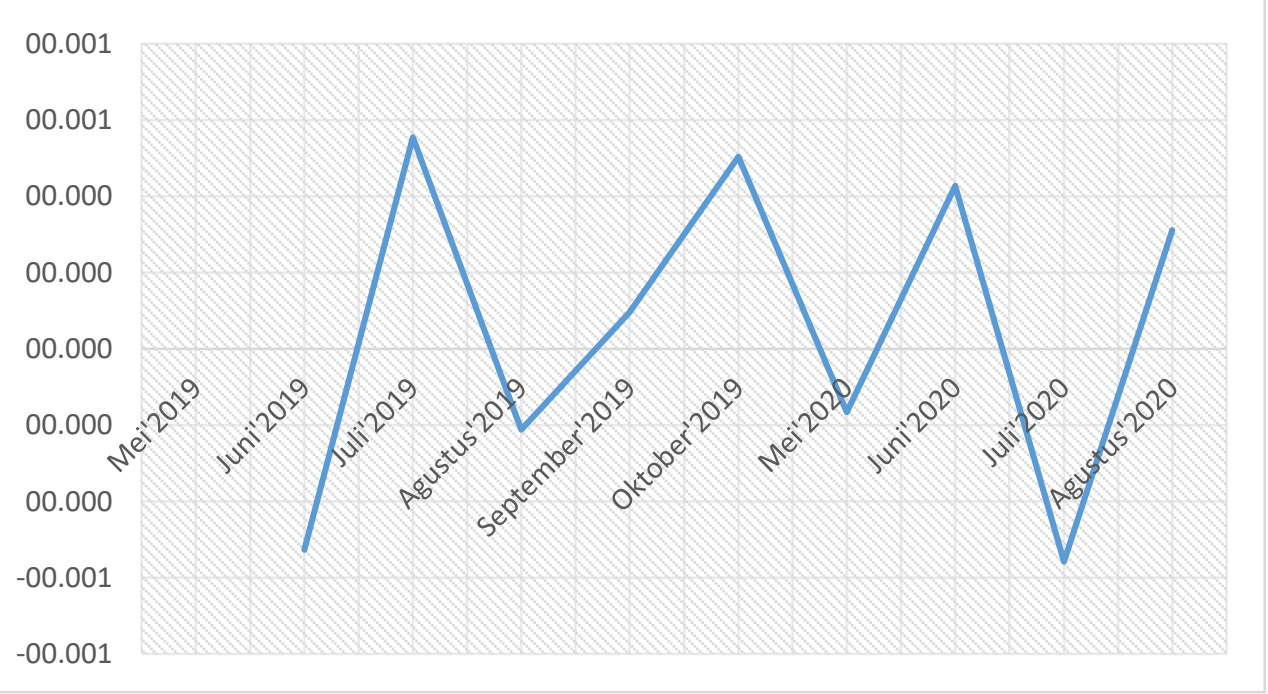

Figure 2 Chart of Changes in Productivity Index

With these product defects, the production process is encouraged to focus on the quality of the product as desired by the customer. To be able to maintain the quality of the resulting product, a problem-solving method with a six-sigma approach is needed, so that the costs or losses caused by defective coffee beans can decrease every year. To be able to produce quality products, it is 
necessary to control every process from the initial purchase of raw materials to delivery of products to customers. The application of the six-sigma method in this study focuses more on how companies can improve their production processes to reducing defects. The use of six sigma is carried out using a systematic stage of DMAIC to achieve zero defects in a process [3].

So in this study discusses how to reduce the level of defects in coffee beans by using the quality improvement method by following the stages in six sigma, and looking for the main causes of defects in coffee beans.

\section{Theoritical Review}

Antony, Vinodh \& Gijo (2016: 27) in a book entitled Lean Six Sigma for Small and Medium Sized Enterprises states that six sigma has three meanings, namely, quality measurement, business improvisation in terms of strategy and philosophy (management system), and methodology [4]. In terms of quality control, six sigma is basically a target to be achieved by the company. Also referred to as an indicator of the achievement of a process.

Six Sigma were pioneered by Motorula in the 1980s. Six Sigma is a statistical concept to measure process capability related to defects. Six Sigma is a method for developing and delivering products to near perfection. DPMO and sigma values become one of the measurement indicators in determining how often defects occur [5]. A company that has reached the level of six sigma is not necessarily free from any defects. The company managed to maintain their defect tolerance of 3.4 Defects per Million Opportunities (DPMO). Therefore, six sigma can be used to measure industrial performance [6].

Six Sigma has a strategic objective to reduce the occurrence of defects in a production process with the ultimate goal of reducing process variation through special improvement programs and structured methods [7]. Jacobs (2015:20) in the book Cultural Impact on Lean Six Sigma and Corporate Success, one method of process improvement in Six Sigma is DMAIC, namely Define (formulate or identify), Measure, Analyze, Improve, and Control [8]. DMAIC is a continuous improvement process towards Six Sigma targets. DMAIC is carried out systematically, based on science and facts, this is also an advantage of six sigma when compared to other quality improvement concepts. The data processing process with six sigma uses several tools in each phase or stage with the aim of making it easier to determine the cause of the problem and determine research improvement proposals. The application of the six-sigma method in this study focuses more on how the company can solve a problem to find and eliminate the causes of defects in business processes. 


\section{Methodology}

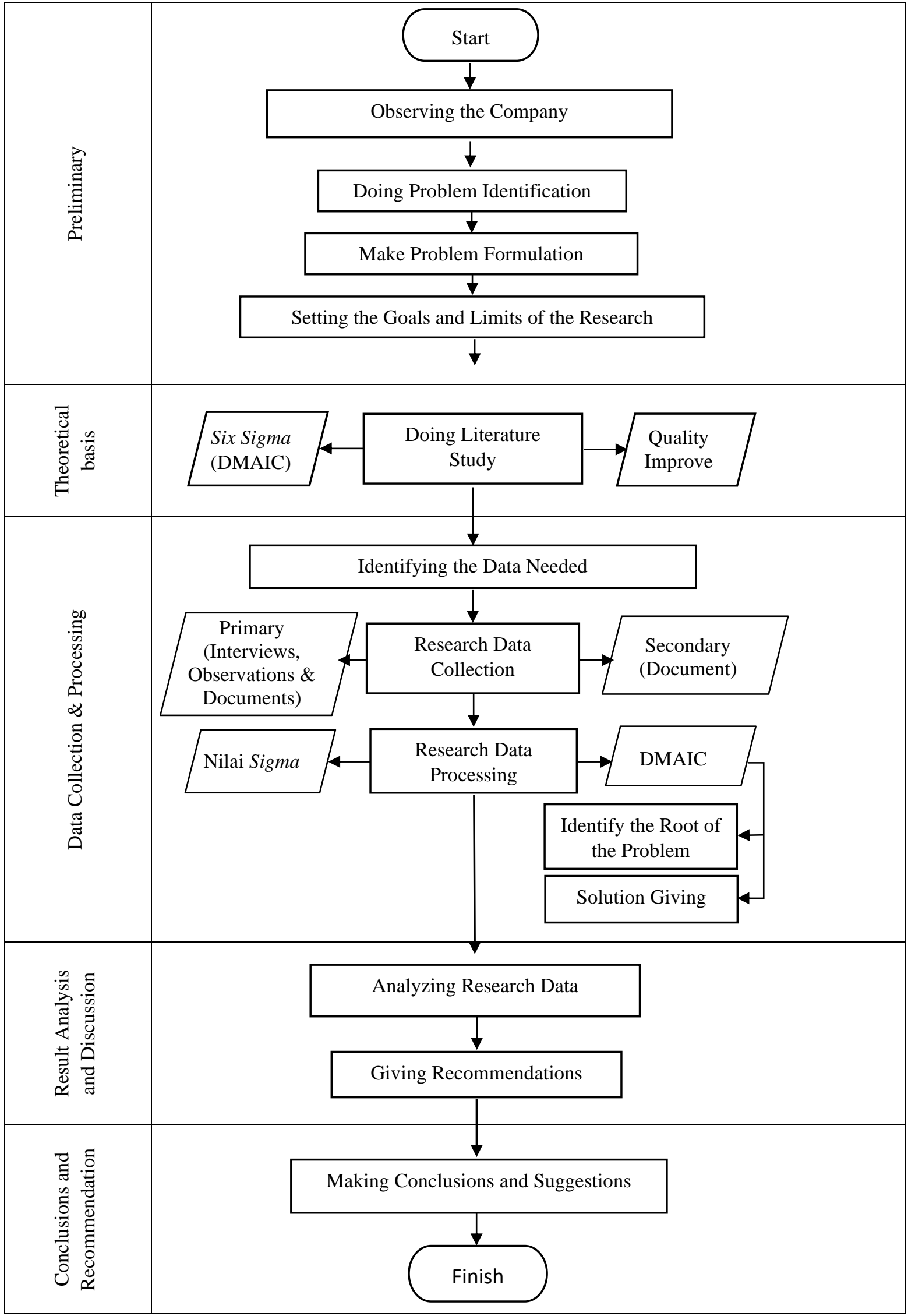

Figure 3 Research Methodology 


\section{Results and Discussion}

\subsection{Phase Define}

\section{A. $\quad$ Project Charter}

Project charter is a tool that contains background and project improvement plans. The project charter in this study is shown in Table 3.

Table 3 Project Charter

\begin{tabular}{|c|c|}
\hline \multicolumn{2}{|c|}{ Project Charter } \\
\hline \multicolumn{2}{|l|}{ Project Name: } \\
\hline \multicolumn{2}{|c|}{ Quality Improvement to Reduce the Number of Defective Coffee Beans Through the Six Sigma Method } \\
\hline \multicolumn{2}{|l|}{ Case Study: } \\
\hline \multicolumn{2}{|c|}{$\begin{array}{l}\text { PT XYZ is a company engaged in the purchase and processing of coffee beans, and in previous studies } \\
\text { there were fluctuations in the level of productivity this was caused by the large number of defective } \\
\text { coffee beans. There has been an increase in the percentage of defects in the last } 5 \text { years. By reducing the } \\
\text { presentation of defective coffee beans, it will increase income for the company. This study uses the Six } \\
\text { Sigma DMAI method to improve quality and reduce the presentation of the number of defects. }\end{array}$} \\
\hline Problems/Opportunities: & Scope and Limits: \\
\hline $\begin{array}{l}\text { There is an increase in the number of defective coffee } \\
\text { beans }\end{array}$ & Production and Procurement Department \\
\hline Project Goal: & Team Member: \\
\hline $\begin{array}{l}\text { Determining the causes of defects in the coffee bean } \\
\text { processing. } \\
\text { Provide recommendations or suggestions for } \\
\text { improvement to reduce the number of product defects. }\end{array}$ & $\begin{array}{l}\text { Sri Wahyuni Matajang } \\
\text { Ir. Erlinda Muslim } \\
\text { Aminah Lang R }\end{array}$ \\
\hline Project Location: & Project Stage: \\
\hline $\begin{array}{l}\text { Ge'tengan Arabica Coffee Bean Processing Industry, } \\
\text { Mengkendek, Tana Toraja, South Sulawesi Province, } \\
\text { Indonesia }\end{array}$ & $\begin{array}{l}\text { Define } \\
\text { Measure } \\
\text { Analyze } \\
\text { Improve } \\
\text { Control }\end{array}$ \\
\hline
\end{tabular}

\section{B. $\quad$ SIPOC Diagrams (Supplier, Input, Process, Output, Customer)}

SIPOC diagrams can be used to identify problems that occur in the process by grouping various elements related to the process [10]. The SIPOC diagram aims to illustrate the process that occurs at PT XYZ, so that with an overview of this process it can make it easier to understand the process from suppliers to customers. In general, those who act as suppliers are suppliers who provide the raw materials needed in processing coffee beans, while the customer as the customer or recipient of finished goods is Starbucks America. 
Table 4 SIPOC Diagram

\begin{tabular}{|l|l|l|l|l|}
\hline SUPPLIER & \multicolumn{1}{|c|}{ INPUT } & PROCESS & OUTPUT & CUSTOMER \\
\hline Farmer & Coffee Bean Raw Material & Purchase & Export Coffee Beans & Amerika Starbucks \\
\hline Farmers & Labor & Processing & & \\
\hline Collector & Machinery and Equipment & Sorting & & \\
\hline & & Packaging & & \\
\hline
\end{tabular}

\section{Overall Process Visualization with Process Chart}

The following describes a flow chart or flow chart from the beginning to the end of the coffee bean production process. This process chart presents a visualization of the entire production process operation in a simple and easy-to-understand form. Flowcharts are used in analyzing, designing, documenting or managing a process or program in various fields, so as to make it easier to determine the scope of the process being examined.

Table 5 Diagram of Export Coffee Bean Production Process

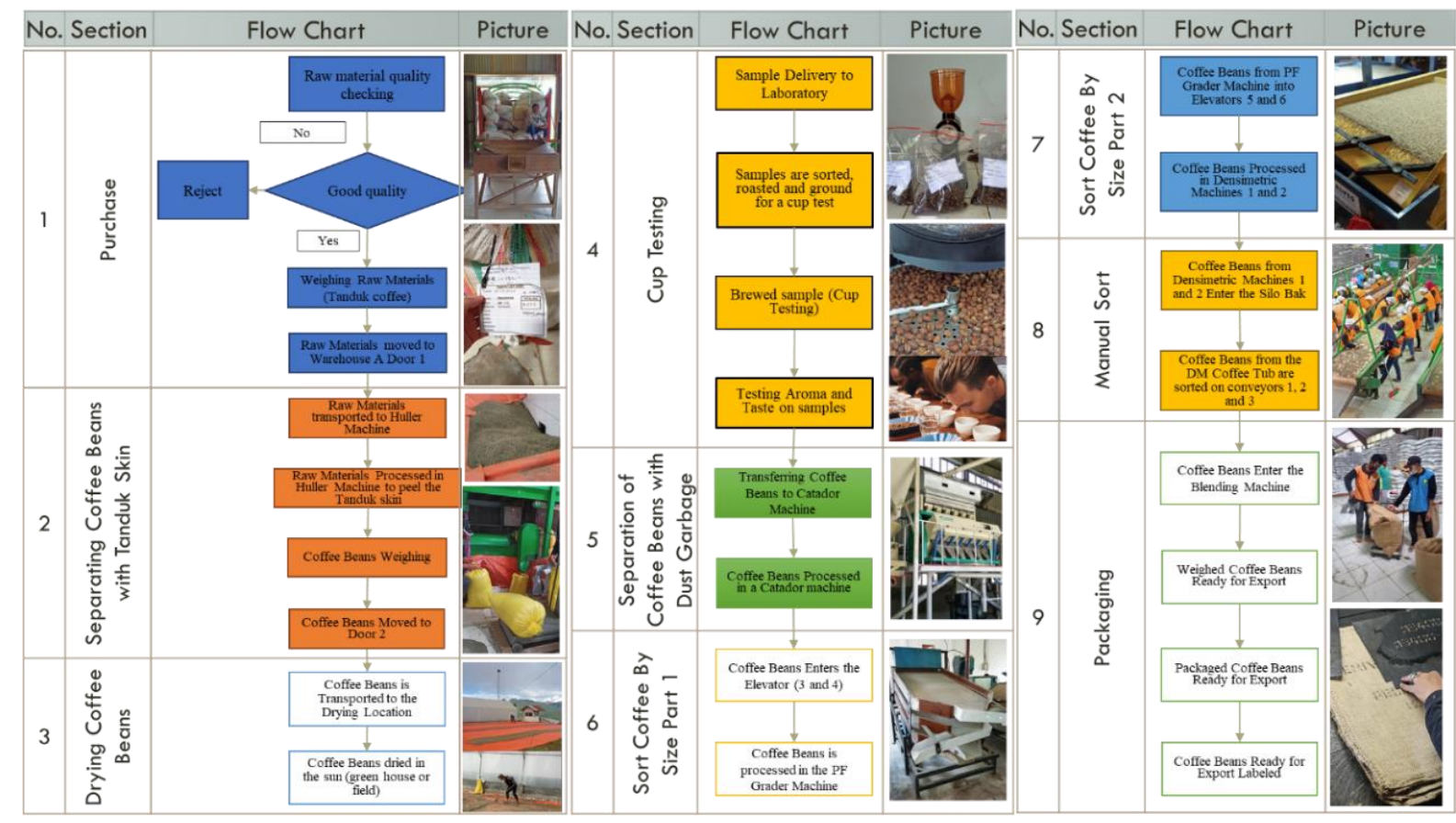

\section{Data Reject Part (Pareto)}

To find out what factors influence defects in coffee bean production at PT XYZ, processing was carried out using Pareto tools using data from May 30, 2020 to October 30, 2020. From the total number of defects obtained, the causes of defects were identified using a Pareto diagram. Defects based on size that have the largest percentage are obtained from pixel defects (size) in the production process with a percentage of $84 \%$. 


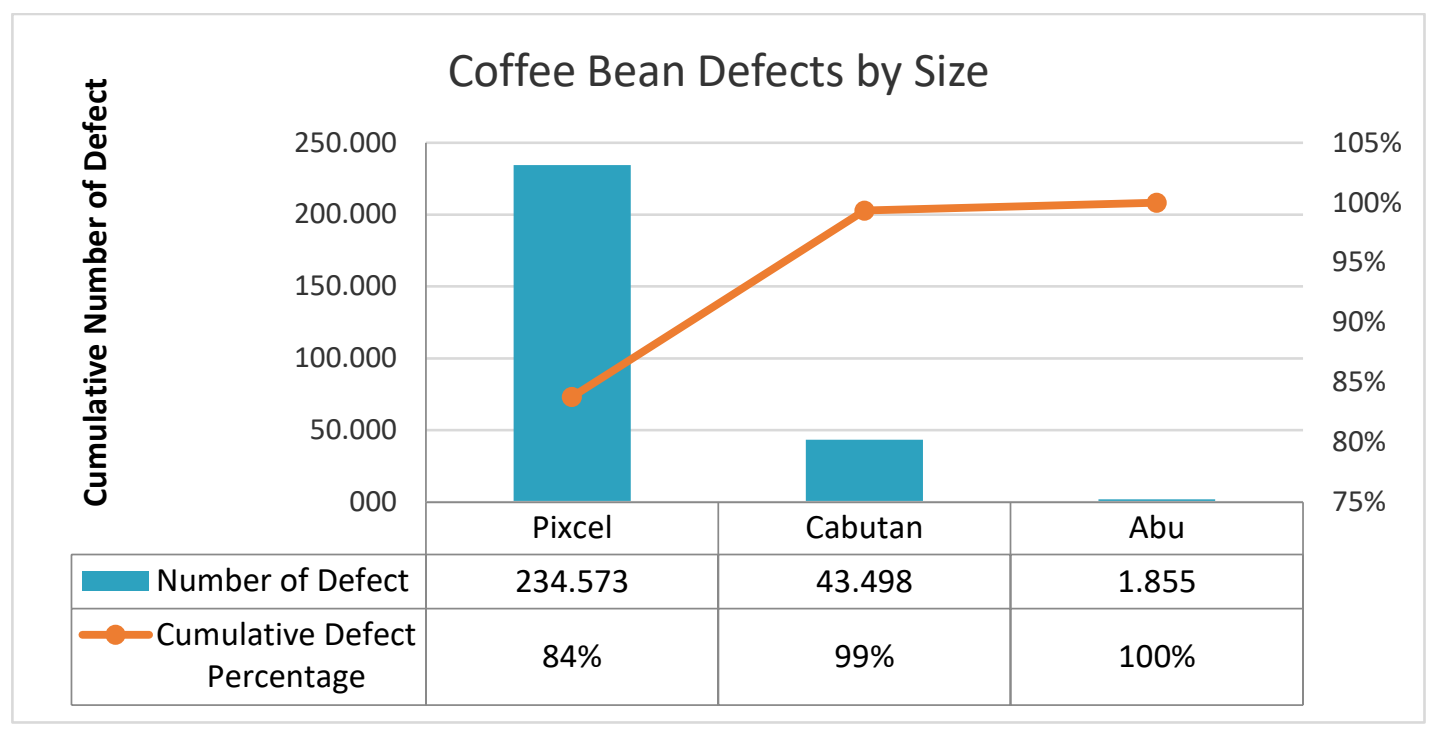

Figure 4 Pareto Diagram of Defects by Size

From the results of data processing above we can find out the problem of Defects based on the size which has the largest percentage obtained from defect pixels (size) in the production process with a percentage of $84 \%$. Pixcel defect is a coffee bean defect that has a size smaller than $5 \mathrm{~mm}$, and comes from Grader and Densimetric Machines. The second most is obtained from cabutan defect in the production process with a percentage of $15 \%$. Cabutan defect is a coffee bean defect that has a size larger than $5 \mathrm{~mm}$ and comes from the processing of a conveyor machine. The third most is obtained from the abu (ash) defect in the production process with a percentage of $1 \%$. The abu (ash) defect is a coffee bean defect that is very small in size and comes from a Catador machine. Coffe beans that have a black color or any color do not match the standard color of coffe bean export and do not match the standard shape of coffe bean export at the manual shorting stage, they will be sorted or selected and then collected in the defect countainer bucket.

To answer the purpose of implementing the Six Sigma methodology, namely to reduce the percentage of defective coffee beans in the production process by improving the process that affects the occurrence of the defect, namely the Pixel defect production process, because it has the largest percentage and more than $84 \%$ in the end it is hoped that all defects can be eliminated. all with a good process.

\subsection{Phase Measure}

\section{A. $\quad$ Critical to Quality/CTQ}

At this stage, a CTQ tree will be drawn for pixel defects. The CTQ contains the characteristics of the coffee bean product that the customer wants. The customer's wishes referred to here include the Indonesian National Standard (SNI) which has been set as a standard that becomes a reference in determining quality. 


\section{Targets \\ Determinant \\ CTQ}

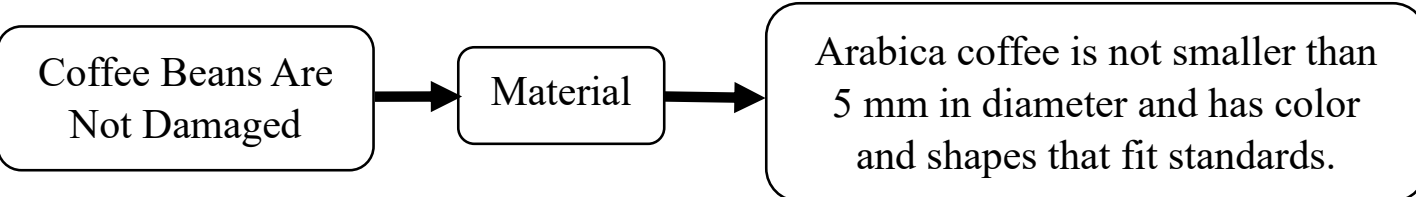

Figure $5 C T Q$ Tree

A product has one type of determinant to be categorized as a defect, namely material, thus the total CTQ is 1 . If the final product meets one of these CTQs, it can be said to be of good quality.

\section{B. Data Colletcion}

Defect data collection is carried out through coffee bean production reports in the production process by the production division. Defect data is taken from coffee bean products for one year.

Table 6 Data on Raw Materials, Production, and Defects 30 May - 30 October 2020

\begin{tabular}{|c|c|c|c|c|c|c|}
\hline No & Date & $\begin{array}{c}\text { Coffee } \\
\begin{array}{c}\text { Bean Raw } \\
\text { Material }\end{array} \\
(\mathrm{Kg})\end{array}$ & $\begin{array}{c}\text { Dried } \\
\text { Green } \\
\text { Seeds } \\
(\mathrm{Kg})\end{array}$ & $\begin{array}{c}\begin{array}{l}\text { Export } \\
\text { Coffee } \\
\text { Beans }\end{array} \\
(\mathrm{Kg})\end{array}$ & $\begin{array}{c}\begin{array}{c}\text { Total } \\
\text { Number of } \\
\text { Defects }\end{array} \\
(\mathrm{Kg})\end{array}$ & \% Defect \\
\hline 1 & $30 / 05 / 2020$ & $21.163,00$ & $10.431,00$ & $9.240,00$ & $1.191,20$ & $11 \%$ \\
\hline 2 & $01 / 06 / 2020$ & $20.283,00$ & $9.878,00$ & $8.880,00$ & 998,00 & $10 \%$ \\
\hline 3 & $02 / 06 / 2020$ & $23.102,00$ & $11.246,00$ & $10.500,00$ & 746,60 & $7 \%$ \\
\hline 4 & $03 / 06 / 2020$ & $21.986,00$ & $10.802,00$ & $10.020,00$ & 782,40 & $7 \%$ \\
\hline ..... & $\ldots \ldots$ & $\ldots .$. & $\ldots .$. & $\ldots .$. & $\ldots .$. & $\ldots .$. \\
\hline 123 & $26 / 10 / 2020$ & $14.501,00$ & $6.861,00$ & $4.500,00$ & $2.361,30$ & $34 \%$ \\
\hline 124 & $27 / 10 / 2020$ & $23.838,00$ & $11.444,00$ & $8.460,00$ & $2.984,20$ & $26 \%$ \\
\hline 125 & $28 / 10 / 2020$ & $22.514,00$ & $10.957,50$ & $8.220,00$ & $2.737,50$ & $25 \%$ \\
\hline \multirow[t]{2}{*}{126} & $30 / 10 / 2020$ & $12.842,00$ & $6.201,10$ & $3.540,00$ & $2.661,10$ & $43 \%$ \\
\hline & Total & 2.733 .158 & 1.310 .786 & 1.030 .860 & $279.926,40$ & $21 \%$ \\
\hline
\end{tabular}

\section{Calculation of Sigma and Yield Nilai Values}

\section{Calculation of Sigma Value}

- Calculating the Total DPU amount

Obtained from the calculation of the Total Defect Value Per Unit is 0.1790.

$$
D P U=\frac{\text { Number of Defects }(D)}{\text { Number of units }(U)}
$$

- Counting the number of Opportunities (Opp) 
The number of opportunities for a product to be said to be defective is called Opportunity. The number of opportunities is the same as the previously identified CTQ number. The number of Opportunities (Opp) for each 1 unit of product is 1 .

- Calculating Defects per Opportunity (DPO)

$$
\mathrm{DPO}=\mathrm{DPU} / \mathrm{Opp}
$$

With a result 0,1790

- Calculating the number of Defects per Million Opportunity (DPMO)

$$
\mathrm{DPMO}=\mathrm{DPO} \times 1.000 .000
$$

With a result 178955,93

- Calculating Sigma Level

Sigma levels are calculated using Microsoft Excel with the following formula (4) [9].

$$
\text { The Excel formula }=\text { NORMSINV }((1,000 . \text { DPMO }) / 1,000,000)+1,5
$$

With a result 2.42

The result of the sigma value from the calculation with the number of DPMO 178,955.93 is 2.42. This DPMO figure means that for every one million production times, the probability of a defect is 178,956 . Because this figure is still at the 2.42 sigma level, it is still necessary to make improvements to increase the sigma level.

\section{Yield Value Calculation}

The ability of a process to produce a product that is not defective is called yield. In addition, the yield value is a number used to measure the performance of a process and identify how many additional production processes will be carried out.

- Opportunity Level Yield

$$
Y=\frac{(\text { T Produksi } \times \text { opp })-\text { Total Jumlah Cacat }}{(\text { T Produksi } \times \text { opp })} \times 100 \%
$$

Then, $\mathrm{Y}=82,10 \%$

- Throughput Yield

$$
Y=1-\frac{\text { Total Jumlah Cacat }}{(\text { T Produksi })} \times 100 \%
$$

Then, $\mathrm{Y}=82,10 \%$ 
The calculation of various types of yield values is carried out as a comparison material. The resulting Opp Level Yield and Throughput Yield values have a high value of 82.10\%. A high value indicates that a unit has a high probability of being said to be defective. The following is a collection of the results of the calculation of DPMO, sigma value, and yield using 126 data from production.

Table 7 DPMO Calculation Results, Sigma Value, and Yield

\begin{tabular}{|c|c|c|c|c|c|c|c|c|c|}
\hline \multirow[t]{2}{*}{ No. } & $\begin{array}{c}\text { Dried Green } \\
\text { Seeds (U) }\end{array}$ & $\begin{array}{l}\text { Number of } \\
\text { Defects (D) }\end{array}$ & \multirow[t]{2}{*}{ (DPU) } & \multirow[t]{2}{*}{ Opp } & \multirow[t]{2}{*}{ (TOP) } & \multirow[t]{2}{*}{ (DPO) } & \multirow[t]{2}{*}{ (DPMO) } & \multirow{2}{*}{$\begin{array}{l}\text { Sigma } \\
\text { Level }\end{array}$} & \multirow[t]{2}{*}{ Yield } \\
\hline & $(\mathrm{Kg})$ & $(\mathrm{Kg})$ & & & & & & & \\
\hline 1 & 10.431 & 920 & 0,0882 & 1 & 10431 & 0,088 & 88196,95 & 2,85 & $91,18 \%$ \\
\hline 2 & 9.878 & 740 & 0,0749 & 1 & 9878 & 0,075 & 74913,95 & 2,94 & $92,51 \%$ \\
\hline 3 & 11.247 & 497 & 0,0442 & 1 & 11247 & 0,044 & 44191,13 & 3,20 & $95,58 \%$ \\
\hline 4 & 10.802 & 470 & 0,0435 & 1 & 10802 & 0,044 & 43508,85 & 3,21 & $95,65 \%$ \\
\hline 5 & 10.365 & 860 & 0,0830 & 1 & 10365 & 0,083 & 82970,74 & 2,89 & $91,70 \%$ \\
\hline 6 & 10.388 & 553 & 0,0532 & 1 & 10388 & 0,053 & 53233,48 & 3,11 & $94,68 \%$ \\
\hline & & & & ..... & & & & & \\
\hline 123 & 6.861 & 2.028 & 0,2956 & 1 & 6861 & 0,296 & 295570,81 & 2,04 & $70,44 \%$ \\
\hline 124 & 11.444 & 2.611 & 0,2282 & 1 & 11444 & 0,228 & 228150,50 & 2,24 & $77,18 \%$ \\
\hline 125 & 10.958 & 2.363 & 0,2157 & 1 & 10958 & 0,216 & 215651,38 & 2,29 & $78,43 \%$ \\
\hline \multirow[t]{2}{*}{126} & 6.201 & 2.467 & 0,3978 & 1 & 6201 & 0,398 & 397832,64 & 1,76 & $60,22 \%$ \\
\hline & $1.310 .786,4$ & 234.573 & 0,1790 & 1 & 1310786 & 0,179 & 178955,93 & 2,42 & $82,10 \%$ \\
\hline
\end{tabular}

\subsection{Phase Analyze}

\section{A. Identifying Causes of Defects with Pareto Charts}

The data used in making this Pareto diagram is the cause of the occurrence or number of pixel defects. The main cause (84\%) of coffee beans become defect pixels or coffee beans that have a diameter smaller than $5 \mathrm{~mm}$, which comes from the coffee bean material or raw materials used that are not good, then $14 \%$ is caused by machines, and $5 \%$ is caused by drying process. The results obtained from the Pareto diagram will then be analyzed further.

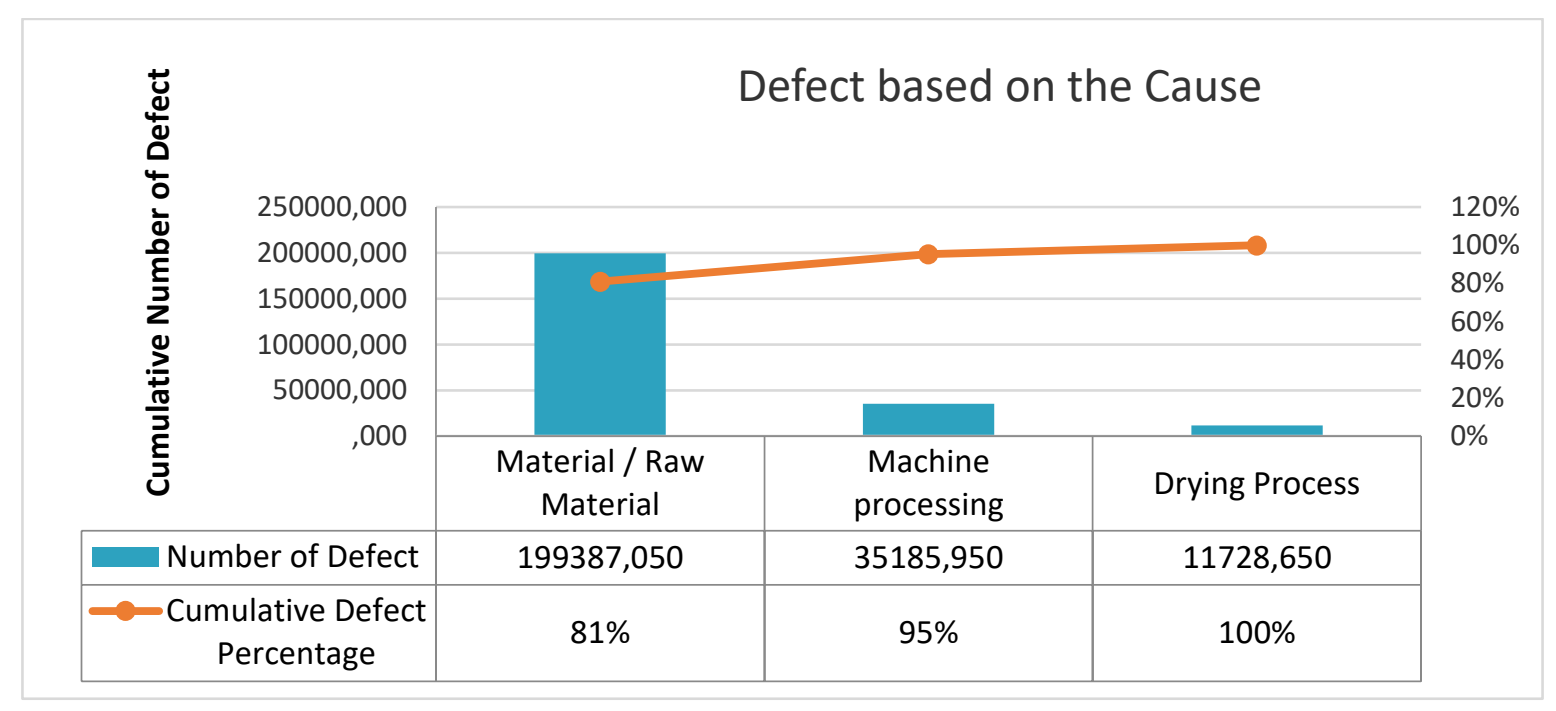

Figure 6 Pareto Defect Diagram based on Causative Factors 


\section{B. Identifying Defects with Causes-and-Effect Diagrams}

Cause and effect diagram is a diagram that shows the relationship between cause and effect. Cause-and-effect diagrams are used to show the causal factors (cause) and the effects caused by these causal factors (effect). Based on the results of brainstorming conducted with the production staff, it was found that the causes of the problems were divided into three categories, namely materials, environment, and machines.

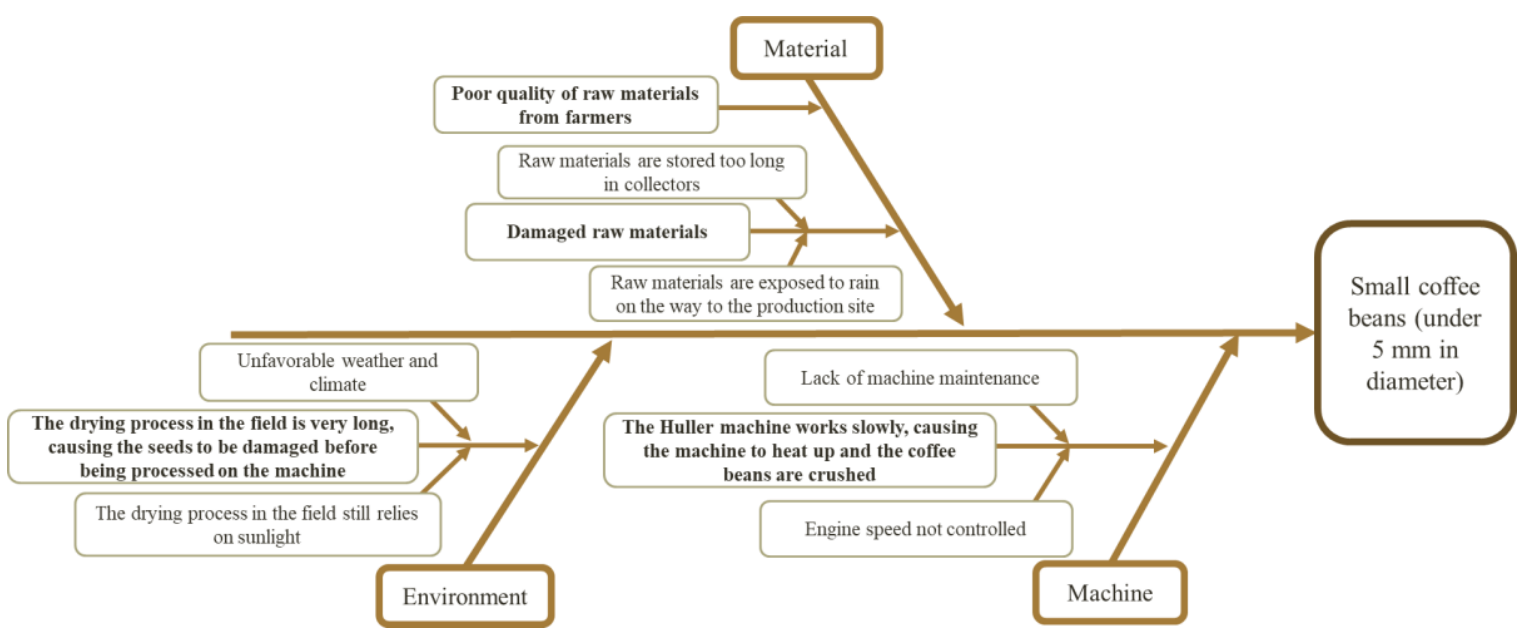

Figure 7 Cause and Effect Diagram

\section{Identifying Root Causes with CFME Diagrams}

Root cause analysis is a technique used to clearly determine the cause of a problem. The reason for this question can be determined by asking a "why" question until further answers to this question no more answers may need to be given.

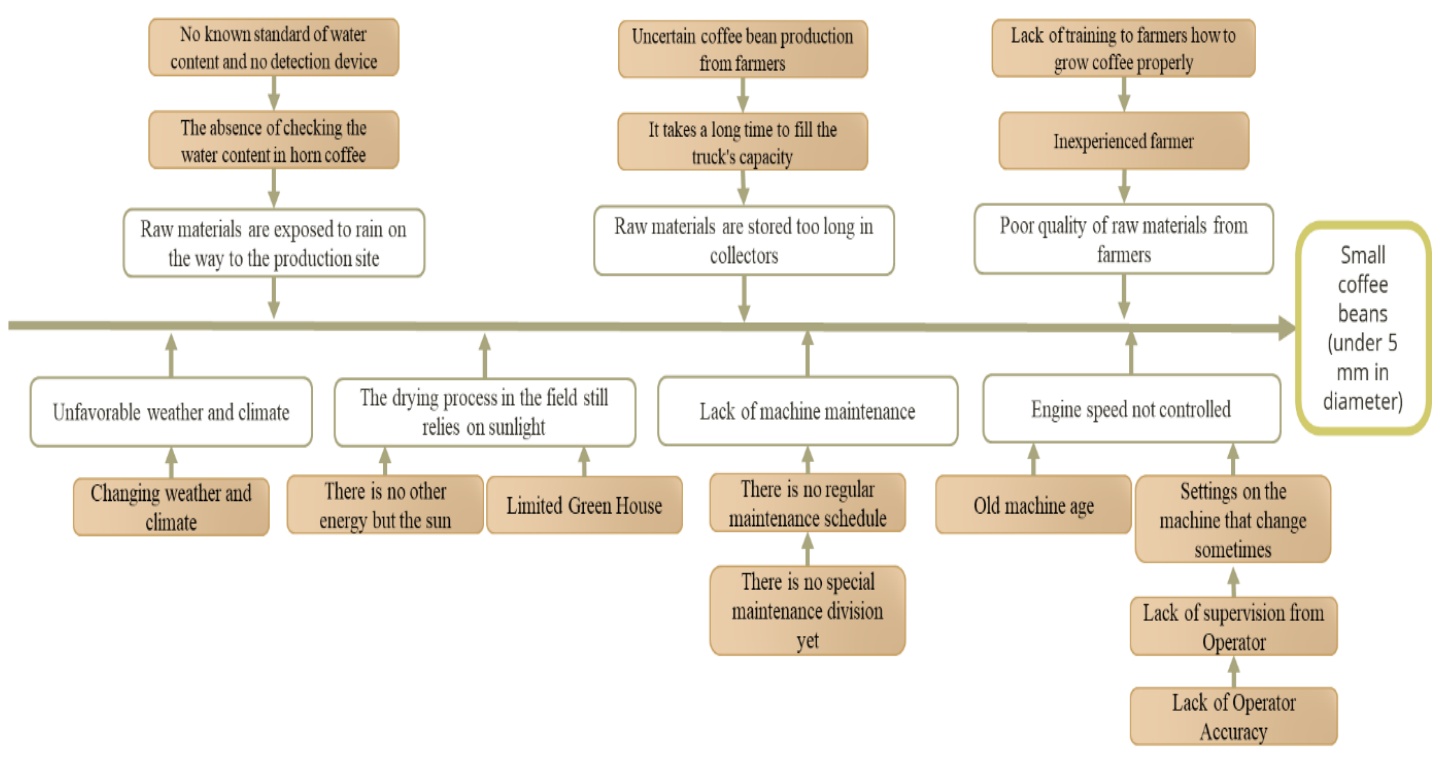

Figure 8 CFME Diagram 


\section{Determining Risk Priorities with FMEA}

The next analytical step is to analyze the potential for potential process failures and prioritize risks to determine appropriate actions in the implementation phase of the proposed improvements that will be recommended later. Each failure mode has a different level of impact, so the first step is to eliminate the cause of the failure mode that poses the greatest risk. So, at this stage the Six Sigma tools called Failure Modes and Effect Analysis (FMEA) are used.

Table 8 Failure Modes and Effect Analysis (FMEA)

\begin{tabular}{|c|c|c|c|c|c|c|c|c|}
\hline $\begin{array}{l}\text { Process } \\
\text { Function }\end{array}$ & $\begin{array}{c}\text { Potential } \\
\text { Failure Modes } \\
\text { (Proses Defects) }\end{array}$ & Potential Failure Effect & 辇 & $\begin{array}{c}\text { Potential } \\
\text { Causes of Failure }\end{array}$ & ̊̊ & 䑁 & $\frac{\pi}{Z}$ & Rank \\
\hline Purchase & $\begin{array}{l}\text { Raw materials are } \\
\text { stored too long in } \\
\text { collectors }\end{array}$ & $\begin{array}{c}\text { The raw material that } \\
\text { comes first will be } \\
\text { damaged }\end{array}$ & 7 & $\begin{array}{l}\text { Uncertain coffee } \\
\text { bean production } \\
\text { from farmers }\end{array}$ & 4 & 6 & 168 & 1 \\
\hline Purchase & $\begin{array}{l}\text { Raw materials are } \\
\text { exposed to rain on } \\
\text { the way to the } \\
\text { production site }\end{array}$ & $\begin{array}{l}\text { The company buys } \\
\text { wet coffee beans }\end{array}$ & 6 & $\begin{array}{c}\text { No known } \\
\text { standard of water } \\
\text { content and no } \\
\text { detection device }\end{array}$ & 2 & 4 & 48 & 4 \\
\hline Machine & $\begin{array}{l}\text { Lack of machine } \\
\text { maintenance }\end{array}$ & $\begin{array}{c}\text { The engine is easy to } \\
\text { heat \& the speed is } \\
\text { not controlled }\end{array}$ & 5 & $\begin{array}{l}\text { There is no } \\
\text { special } \\
\text { maintenance } \\
\text { division yet }\end{array}$ & 6 & 4 & 120 & 2 \\
\hline \multirow[b]{2}{*}{ Machine } & \multirow[b]{2}{*}{$\begin{array}{l}\text { Engine speed not } \\
\text { controlled }\end{array}$} & $\begin{array}{l}\text { Coffee beans that are } \\
\text { being processed are } \\
\text { crushed or chopped }\end{array}$ & 4 & $\begin{array}{l}\text { Lack of Operator } \\
\text { Accuracy }\end{array}$ & 5 & 4 & 80 & 3 \\
\hline & & $\begin{array}{l}\text { The need for extra } \\
\text { supervision from the } \\
\text { operator of the engine } \\
\text { speed }\end{array}$ & 3 & $\begin{array}{l}\text { Age of the old } \\
\text { machine }\end{array}$ & 4 & 2 & 24 & 6 \\
\hline \multirow{2}{*}{ Drying } & \multirow{2}{*}{$\begin{array}{l}\text { The drying } \\
\text { process in the } \\
\text { field still relies on } \\
\text { sunlight }\end{array}$} & $\begin{array}{l}\text { During the rainy } \\
\text { season, coffee beans } \\
\text { that are dried in the } \\
\text { field will get moldy }\end{array}$ & 3 & $\begin{array}{c}\text { Limited Green } \\
\text { House }\end{array}$ & 5 & 3 & 45 & 5 \\
\hline & & $\begin{array}{l}\text { The current drying } \\
\text { process depends on } \\
\text { the weather }\end{array}$ & 2 & $\begin{array}{l}\text { There is no other } \\
\text { energy but the sun }\end{array}$ & 4 & 2 & 16 & 7 \\
\hline Drying & $\begin{array}{l}\text { Unfavorable } \\
\text { weather and } \\
\text { climate }\end{array}$ & $\begin{array}{c}\text { During the rainy } \\
\text { season, coffee beans } \\
\text { take a long time to } \\
\text { dry }\end{array}$ & 2 & $\begin{array}{l}\text { Changing weather } \\
\text { and climate }\end{array}$ & 3 & 3 & 12 & 8 \\
\hline
\end{tabular}

\subsection{Phase Improve}

\section{A. Determination of Problem Solutions with Action Plan Table for Failure Modes}

The Action Plan for Failure Modes table is a tool used to determine the most appropriate action to be taken, especially for failure modes with high failure risk. The data used are the results obtained from the Failure Mode and Effects Analysis (FMEA) analysis by looking at the priority order (rank) of the most important failure modes to pay attention to. Because the 
problem and the main focus of this research are improvements to the environment of PT XYZ and farmers are not part of PT XYZ's production, the proposed improvement only focuses on improvements that can be made in and by PT XYZ. As well as the proposed improvements that are taken and implemented are the first five ranks of the proposed improvements.

Table 9 Action Plan for Failure Modes

\begin{tabular}{|c|c|c|c|c|}
\hline Rank & Failure Modes & Actionable Causes & $\begin{array}{c}\text { Desain Action/Potensial } \\
\text { Solution }\end{array}$ & $\begin{array}{l}\text { Design } \\
\text { Validation }\end{array}$ \\
\hline 1 & $\begin{array}{l}\text { Raw materials } \\
\text { are stored too } \\
\text { long in } \\
\text { collectors }\end{array}$ & $\begin{array}{l}\text { Uncertain production } \\
\text { of coffee farmers }\end{array}$ & $\begin{array}{l}\text { Checking the time of } \\
\text { purchase from farmers } \\
\text { before purchasing coffee } \\
\text { beans from collectors }\end{array}$ & $\begin{array}{l}\text { Filling in the } \\
\text { card for } \\
\text { purchasing } \\
\text { coffee beans } \\
\text { from farmers } \\
\text { by collectors }\end{array}$ \\
\hline 2 & $\begin{array}{l}\text { Lack of machine } \\
\text { maintenance }\end{array}$ & $\begin{array}{l}\text { Engine speed not } \\
\text { controlled }\end{array}$ & $\begin{array}{l}\text { Machine inspection and } \\
\text { maintenance or machine } \\
\text { replacement }\end{array}$ & $\begin{array}{c}\text { Create a } \\
\text { maintenance } \\
\text { division and } \\
\text { Machine } \\
\text { Inspection } \\
\text { Schedule } \\
\end{array}$ \\
\hline 3 & $\begin{array}{l}\text { Lack of } \\
\text { Operator } \\
\text { Accuracy }\end{array}$ & $\begin{array}{l}\text { The absence of SOPs } \\
\text { at the station, work, } \\
\text { lack of experience, } \\
\text { and motivation }\end{array}$ & $\begin{array}{l}\text { Providing training to } \\
\text { operators and Making } \\
\text { SOPs and clear work } \\
\text { instructions at each work } \\
\text { station }\end{array}$ & $\begin{array}{l}\text { Employee } \\
\text { Training } \\
\text { There is a } \\
\text { clear SOP for } \\
\text { each process }\end{array}$ \\
\hline 4 & $\begin{array}{l}\text { Poor quality of } \\
\text { raw materials } \\
\text { from farmers }\end{array}$ & $\begin{array}{l}\text { Lack of knowledge } \\
\text { of farmers how to } \\
\text { grow and care for } \\
\text { coffee properly }\end{array}$ & $\begin{array}{l}\text { Provide training to } \\
\text { farmers how to grow and } \\
\text { care for coffee properly }\end{array}$ & $\begin{array}{l}\text { There is a } \\
\text { training } \\
\text { schedule, } \\
\text { training } \\
\text { materials }\end{array}$ \\
\hline 5 & $\begin{array}{l}\text { Raw materials } \\
\text { are exposed to } \\
\text { rain on the way } \\
\text { to the production } \\
\text { site }\end{array}$ & $\begin{array}{l}\text { The absence of a } \\
\text { tool to detect the } \\
\text { water content in } \\
\text { parchment coffee } \\
\text { bean }\end{array}$ & $\begin{array}{l}\text { Buy a water content } \\
\text { detector in parchment } \\
\text { coffee bean for } \\
\text { consideration in } \\
\text { determining the price }\end{array}$ & $\begin{array}{c}\text { Making a } \\
\text { water content } \\
\text { card on } \\
\text { parchment } \\
\text { coffee bean }\end{array}$ \\
\hline 6 & $\begin{array}{c}\text { Limited Green } \\
\text { House }\end{array}$ & $\begin{array}{l}\text { Moldy coffee beans } \\
\text { during the rainy } \\
\text { season }\end{array}$ & Adding Green House & $\begin{array}{l}\text { Addition of } \\
\text { Green House }\end{array}$ \\
\hline 7 & $\begin{array}{l}\text { Age of the old } \\
\text { machine }\end{array}$ & $\begin{array}{l}\text { Coffee beans that are } \\
\text { processed on a } \\
\text { crushed machine }\end{array}$ & $\begin{array}{l}\text { Replacing the Machine } \\
\text { with a new machine, or } \\
\text { performing maintenance }\end{array}$ & $\begin{array}{c}\text { Making } \\
\text { machine } \\
\text { maintenance } \\
\text { schedules, } \\
\text { purchasing } \\
\text { new machines }\end{array}$ \\
\hline 8 & $\begin{array}{l}\text { There is no other } \\
\text { energy but the } \\
\text { sun }\end{array}$ & $\begin{array}{l}\text { During the rainy } \\
\text { season, the drying } \\
\text { process for coffee } \\
\text { beans is very long }\end{array}$ & $\begin{array}{c}\text { Add a Green House or } \\
\text { buy a coffee bean dryer } \\
\text { Changing weather and } \\
\text { climate }\end{array}$ & $\begin{array}{c}\text { Addition of } \\
\text { Green House, } \\
\text { and Purchase } \\
\text { of coffee bean } \\
\text { dryer }\end{array}$ \\
\hline
\end{tabular}




\subsection{Phase Control}

Based on the results of the identification of three types of causes of coffee bean defects using the FMEA and RPN methods that have been carried out to determine the most critical and urgent priorities to be handled, it is known that raw materials stored too long in the collectors are caused by the production of farmers who erratic with the highest RPN value of 168 and also a high severity value of 7 and the second highest RPN value is the lack of maintenance on the machine is known because there is no special maintenance division with an RPN value of 120 and a severity level of 5. Based on the results of FMEA brainstorming with parties' companies in the field of production that have been carried out, then the highest 5 RPNs are selected with various proposals and then the output proposals are submitted to PT. XZY to do:

- Make a card to check the date of purchase of coffee beans from farmers and a card for the moisture content of parchment coffee bean when purchasing coffee beans

Coffee beans if stored for too long will cause a decrease in the quality of the coffee beans, while new collectors will send coffee beans when the capacity of the coffee transporter is full. In addition to the water content in parchment coffee bean also affects the quality of the raw materials. To anticipate companies buying parchment coffee bean that are old and have a high-water content, data on the time of purchasing coffee beans for each sack is needed which is signed by farmers and collectors and checks the water content and then fills it in the card as information and reference in determining prices buy parchment coffee beans.

- Create and run maintenance division

Machine maintenance is the main key in the health of the machines used. There are still some companies who are not aware of the importance of routine maintenance for machines. The need to create a special maintenance division and a routine machine maintenance schedule.

- Compile and apply 5 s checklist

The number of workers with their respective duties often becomes a part that is not fully controlled because there is no fixed control system. The 5 s proposed checklist lists what needs to be checked and monitored for convenience, safety, and most importantly an evaluation of the factory situation.

- Develop and implement SOPs

Production communication system and production coordination in the company along with the punishment policy that will be accepted. In making standard operating procedures, workers are expected to care more and work better. The SOPs made contain detailed work steps that are the duties and responsibilities of workers, there are also sanctions or penalties to create a deterrent effect for workers who carry out their work without following the established procedures or SOPs. 


\section{Conclusion}

After carrying out the existing DMAIC stages, the researcher reached the following conclusions: The ability of the coffee bean production process at PT XYZ is assessed using the calculation of the sigma level value. The DPMO value of 0.1790 is obtained from the calculation results and is 2.42 for the sigma value. Identify how many solutions can be used to improve performance and process capability. This identification uses the Table Action Planning for Failure Modes. Some of the main solutions are checking the time of purchasing raw materials from farmers before buying raw materials from collectors, making and scheduling routine inspections of machines or replacing machines that are not suitable for use, providing training to operators and making SOPs and work instructions at each work station, Purchasing a water content detector for coffee raw materials, and the addition of a green house. There are 3 types of defects in PT. XYZ, namely Pixcel, Cabutan, and Abu (ash) each account for 84\%, $16 \%$ and $1 \%$ of the total defect data. Among the three types of defects that exist, the pixcel type is the most common defect in coffee bean processing at PT XYZ, while the cause of this pixcel type consists of 3 main causes, namely Material, Machine, and Drying each of which is $81 \%$, $14 \%$ and $5 \%$.

\section{Suggestion}

There are still some things that need to be developed and improved, considering that in this study there are still many shortcomings. Here are some suggestions for this research and further, the first is that it is necessary to compare the resulting sigma values after and before the implementation of the proposed improvements. In the FMEA formulation and Action Plan Table, it is better to involve all relevant divisions in the company. It is necessary to do a test using P-Chat to see whether the processed data is controlled or not. Because the quality of raw materials plays a very important role in determining the quality of the final product, it is necessary to train farmers on how to plant and care for coffee properly in order to produce quality coffee beans. For further research, it is expected to be able test the data using P-Chat.

\section{REFERENCES}

[1] ICO Staff. "Statistics data International Coffee Organization (ICO)," 2020. [Online]. Available: http://www.ico.org/trade_statistics.asp. [Accessed: Jun. 20, 2021].

[2] Matajang, S. W, "Pengukuran dan Analisis Produktivitas Produksi PT XYZ dengan Menggunakan Metode Objective Matrix (OMAX),” 2020.

[3] Malezka, A., Linke, M, "Improvement of management process by using lean six sigma tools in of food industry," Pol. J. Nat. Sci, vol. 31, pp. 101-112. 2016.

[4] Antony, Vinodh, Gijo, "Lean Six Sigma for Small and Medium Sized Enterprises," vol. 27. 2016. 
[5] R. S. Russell, and B. W. Taylor, Operations Management: Quality and Competitiveness in a Global Environment, Wiley. 2016.

[6] G. Brue. (2002). Six sigma for Managers. A briefcase Book., Mc Graw-Hill.

[7] Gutierrez-Gutierrez, L., Barrales-Molina, V., Fernandez-Giordano, M., and LopezMorales, B, "Six Sigma for Dynamic Capabilities Development: Becoming More Flexible Organizations," International Journal of Lean Six Sigma, vol. 1, no. 1, pp. 3556. 2020.

[8] Mariam.7 Jacobs, Cultural Impact on Lean Six Sigma and Corporate Success, Germany: Springer Gabler, 2015. [Online] Available: Springer Gabler.

[9] Rapaka M P, "Six sigma methods and formulas for successful quality management," Int. J. Eng. Res. Appl, vol. 7, no. 1, pp. 49-52. 2017.

[10] Jowwad, M. S., Gangha G, Indhu B, "Lean six sigma methodology for the improvement of the road construction projects," Int. J. Civ. Eng. Technol, vol. 8, pp. 248-259. 2017. 